ISSN : 2303-1514 | E-ISSN : 2598-5949

\title{
INCREASING TEACHER'S JOB SATISFACTION THROUGH GIVING AWARDS AT SLB NEGERI DURI
}

\author{
Maidar \\ Pengawas Sekolah, Bengkalis, Riau, Indonesia \\ maeka_zu@yahoo.co.id
}
PENINGKATAN KEPUASAN KERJA GURU MELALUI PEMBERIAN PENGHARGAAN DI SEKOLAH LUAR BIASA NEGERI DURI

\begin{tabular}{|c|c|}
\hline ARTICLE HISTORY & ABSTRACT \\
\hline $\begin{array}{l}\text { Submitted: } \\
\text { 13 Juli } 2021 \\
13^{\text {th }} \text { July } 2021\end{array}$ & $\begin{array}{l}\text { Abstract: Job satisfaction is an important target in human resource management because it } \\
\text { will directly or indirectly affect work productivity. Conversely, high satisfaction is desired by } \\
\text { leaders because it can be associated with the positive results they expect. High job satisfaction } \\
\text { indicates that a school organization has been well managed with effective management. This } \\
\text { School Action Research was located at SLB Negeri Duri, which was addressed to teachers at } \\
\text { SLB Negeri Duri. The main reason was that based on the observation, teachers' job } \\
\text { satisfaction was still low. The population in this study was all } 15 \text { teachers at SLB Negeri Duri. } \\
\text { Based on the results of the study, it was known that 1) The aspect of giving rewards brought by } \\
\text { the tutor increased teachers'job satisfaction in the second cycle. If the score the first cycle was } \\
20 \text {, then the second cycle was better by getting a score of } 32 \text {. In the aspect of teachers' job } \\
\text { satisfaction, it was found that the percentage in the first cycle was } 53 \% \text { with a good enough } \\
\text { category and in the second cycle, it increased to } 80 \% \text { with a very good category. This situation } \\
\text { showed that teachers' job satisfaction increased through giving awards at SLB Negeri Duri. }\end{array}$ \\
\hline
\end{tabular}

Keywords: job satisfaction, award

Accepted:

04 September 2021

$04^{\text {th }}$ September2021
Abstrak: Kepuasan kerja (job satisfaction) merupakan sasaran penting dalam manajemen sumber daya manusia, karena secara langsung maupun tidak langsung akan mempengaruhi produktivitas kerja. Sebaliknya kepuasan yang tinggi dinginkan oleh pimpinan karena dapat dikaitkan dengan hasil positif yang mereka harapkan. Kepuasan kerja yang tinggi menandakan bahwa sebuah organisasi sekolah telah dikelola dengan baik dengan manajemen yang efektif. Penelitian Tindakan Sekolah ini berlokasi di Sekolah Luar Biasa Negeri Duri, yang ditujukan pada guru-guru Sekolah Luar Biasa Negeri Duri. Adapun alasan utamanya adalah dari hasil pengamatan bahwa Kepuasan kerja guru masih tergolong kurang. Populasi pada penelitian ini adalah seluruh guru yang ada di Sekolah Luar Biasa Negeri Duri yang berjumlah 15 orang. Berdasarkan hasil penelitian diketahui 1) Aspek pemberian reward yang dibawakan oleh tutor diketahui bahwa dari siklus I meningkat pada siklus II. Jika pada siklus I mendapatkan skor sebesar 20 maka pada siklus II sudah lebih baik dengan mendapatkan perolehan skor sebesar 32. Pada aspek Kepuasan kerja guru didapatkan pada siklus I sebesar 53\% dengan kategori dukup baik dan pada siklus II meningkat menjadi $80 \%$ dengan kategori sangat baik. Keadaan ini menunjukan bahwa Kepuasan kerja guru dapat ditingkatkan melalui pemberian Penghargaan di Sekolah Luar Biasa Negeri Duri.

Kata kunci: kepuasan kerja, penghargaan
Published:

28 Oktober 2021

$28^{\text {th }}$ October 2021

\section{CITATION}

Maidar, M. (2021). Increasing Teacher's Job Satisfaction through Giving Awards at SLB Negeri Duri. Primary: Jurnal Pendidikan Guru Sekolah Dasar, 10 (5), 1279-1287. DOI: http://dx.doi.org/10.33578/jpfkip.v10i4.8540.

\section{PENDAHULUAN}

Sekolah luar biasa adalah tempat dimana anak-anak berkebutuhan khusus menimba ilmu sesuai dengan kekhususannya, dimana anak berkebutuhan khusus juga berhak untuk mendapatkan pendidikan yang layak 
untuk mengembangkan potensi mereka walaupun tetapi dalam kenyataannya masih banyak masalah yang terjadi pada sekolah luar biasa itu sendiri (Kurniaman, Fauziah, \& Noviana, 2021). Masalah yang terjadi antara lain dari segi sumberdaya manusianya, dimana jumlah tenaga pengajar yang ada di sekolah luar biasa masih minim dan terdapat tenaga pengajar yang bukan lulusan dari pendidikan luar biasa (Dewi \& Kurniaman, 2019).

Dari segi ketatalaksanaannya, sekolah luar biasa masih belum memberikan pelayanan yang efektif kepada anak berkebutuhan khusus dalam proses pembelajarannya sehingga anak berkebutuhan khusus belum mampu mengembangkan dirinya. Hal ini terlihat dengan ketidakmampuan anak berkebutuhan khusus dalam mengembangkan potensi akademik maupun non akademiknya (Schmidt, and Brown, 2015). Selain itu, tenaga pengajar juga masih kesulitan untuk merumuskan dan mengimplementasikan makna dari kurikulum yang ada dengan sebuah metode pembelajaran yang nantinya dapat dimengerti oleh anak berkebutuhan khusus. Hal tersebut juga sesuai dengan pendapat Tarmansyah (2009, h.13) yang mengatakan bahwa guru masih belum memahami cara mengasesmen kemampuan anak, karena kurikulum yang ada belum dimodifikasi oleh guru sesuai dengan kebutuhan anak, dari segi sistemnya.

Kepala Sekolah dan pihak birokrasi belum memahami sepenuhnya visi, misi, tujuan dan tatalaksana dari system (Candra, \& Yanto, 2020). Tugas utama Pengawas sekolah adalah melakukan pengawasan terhadap sekolah yang menjadi tanggung jawabnya. Pengawasan dalam konteks ini meliputi pemantauan, supervisi, evaluasi, pelaporan, dan pengambilan langkah tindak lanjut yang diperlukan. Hal itu ditegaskan dalam Peraturan Pemerintah Nomor 19 Tahun 2005 tentang Standar Nasional Pendidikan Pasal 19 ayat (3) yang menetapkan setiap satuan pendidikan melakukan perencanaan proses pembelajaran, penilaian hasil pembelajaran, dan pengawasan proses pembelajaran untuk terlaksananya proses pembelajaran yang efektif dan efisien. Dilanjutkan dengan Pasal 23 yang menegaskan bahwa: Pengawasan proses pembelajaran sebagaimana dimaksud dalam pasal 19 ayat (3) meliputi pemantauan, supervisi, evaluasi, pelaporan, dan pengambilan langkah tindak lanjut yang diperlukan.

Tugas guru sebagai profesi menurut Undang-Undang No. 2 Tahun 1989 tentang Sistem Pendidikan Nasional meliputi mendidik, mengajar dan melatih (Basri, 2019). Mendidik berarti meneruskan dan mengembangkan nilai-nilai hidup, mengajar berarti meneruskan dan mengembangkan ilmu pengetahuan, melatih berarti mengembangkan keterampilan-keterampilan pada siswa (Kurniaman, \& Sismulyasih, 2019). Dalam melaksankan tugasnya guru bekerjasama dengan orang tua dan masyarakat. Tugas guru erat kaitannya dengan peningkatan sumber daya manusia melalui sektor Pendidikan (Kurniaman, Oktari, \& Pahrurazi, 2019).

Guru dituntut untuk bekerja dengan memberikan pelayanan sebaik-baiknya kepada pemakai sekolah seperti siswa, orang tua, dan masyarakat. Salah satu faktor yang menunjang guru untuk bekerja dengan sebaik-baiknya yaitu kepuasan kerja (Bastian, 2019). Artinya jika guru puas terhadap perlakuan organisasi (sekolah) maka mereka akan bekerja penuh semangat dan bertanggung jawab (Novianti, Puspitasari, \& Maria, 2021).

Mangkunegara

mengemukakan bahwa kepuasan kerja (job satisfaction) merupakan sasaran penting dalam manajemen sumber daya manusia, karena secara langsung maupun tidak langsung akan mempengaruhi produktivitas kerja. Sebaliknya kepuasan yang tinggi dinginkan oleh pimpinan karena dapat dikaitkan dengan hasil positif yang mereka harapkan. Kepuasan kerja yang tinggi menandakan bahwa sebuah organisasi sekolah telah dikelola dengan baik dengan manajemen yang efektif (Katrin, 2019). Kepuasan kerja yang tinggi menunjukkan kesesuaian antara harapan dengan imbalan yang disediakan oleh organisasi. Suatu gejala 
yang dapat membuat rusaknya kondisi organisasi sekolah sebagai akibat dari rendahnya kepuasan kerja salah satunya adalah timbulnya gejala tidak disiplin dalam melaksanakan tugas. Dampak dari ketidakdisiplinan ini akan mengakibatkan kerugian bahkan jatuhnya instansi/perusahaan itu sendiri.

Bila dilihat dalam hal kepuasan kerja guru, dijumpai fenomena antara lain; adanya sebagian guru yang merasa kurang puas dengan gaji yang diterima. Adanya sebagian guru yang merasa kurang dilibatkan dalam kegiatan-kegiatan yang dilaksanakan oleh dinas seperti kegiatan pelatihan kurikulum dan sebagainya. Adanya sebagian guru yang mengatakan kurang harmonisnya hubungan antara guru dengan guru maupun guru dengan kepala sekolah.

\section{METODE PENELITIAN}

Metode penelitian yang dilakukan adalah menggunakan model penelitian tindakan sekolah yang dikembangkan oleh Kemmis \& Taggart (2010), dimana pada prinsipnya ada empat tahap kegiatan yaitu, perencanaan tindakan (planning), pelaksanaan tindakan (action), observasi dan evaluasi proses tindakan (observation and evaluation) dan melakukan refleksi (reflecting).

Penelitian Tindakan Sekolah ini berlokasi di SLB Negeri Duri, yang ditujukan pada guru-guru SLB Negeri Duri. Adapun alasan utamanya adalah dari hasil pengamatan bahwa Kepuasan kerja guru masih tergolong kurang. (Arikunto, Suhardjono, \& Supardi, 2012) mengemukakan populasi adalah keseluruhan subjek penelitian. Populasi pada penelitian ini adalah seluruh guru yang ada di SLB Negeri Duri yang berjumlah 15 orang. Jika kita hanya akan meneliti sebagian dari populasi, maka penelitian tersebut disebut penelitian sampel. Sampel adalah sebagian atau wakil populasi yang diteliti. mengingat jumlah populasinya kecil, maka seluruh populasi dijadikan sampel. Dengan demikian jumlah sampel dalam penelitian ini adalah 15 orang. Teknik pengumpulan data menggunakan instrument lembar observasi, lembar penilaian, dan kepuasan kerja guru.

\section{HASIL DAN PEMBAHASAN}

Penelitian tindakan kelas ini dilaksanakan sesuai dengan perencanaan hingga evaluasi yang sudah disusun sebelumnya dengan tahapan-tahapan sebagai berikut :

\section{Siklus I}

a. Perencanaan.

Kegiatan penelitian ini direncanakan berlangsung selama dua siklus, mulai bulan februari s/d bulan Maret 2019 di SLB Negeri Duri, Perencanaan penelitian meliputi: Pertemuan dengan guru - guru, menginformasikan tentang pelaksanaan penelitian. Peneliti menyiapkan skenario yang akan dilaksanakan selama proses tindakan yaitu tengtang kedisiplinan dalam menjalankan tugas . menyiapkan instrumen penelitian. Merencanakan pertemuan awal. Perbaikan proses pembelajaran dengan metode demonstrasi dalam siklus pertama. Proses pembelajaran diawali dengan menyajikan beberapa informasi yang berkaitan dengan Kepuasan kerja. Dalam kegiatan ini peneliti melakukan Tanya jawab tentang Kepuasan kerja dalam menjalankan tugas .

b. Pelaksanaan.

1) Memusatkan perhatian kepada guru agar mengikuti arahan yang diberikan oleh fasilitator

2) Menjelaskan materi pelajaran dengan kalimat yang memberikan motivasi

3) Memuji dan menyanjung di depan guru yang lain jika menjawab benar

4) Memberikan tugas dengan suasana santai seperti membuat rencana pelaksanaan pembelajaran dengan beberapa model pembelajaran

5) Membahas tugas yang telah dikerjakan guru

6) Membebaskan guru dari sebagian kewajiban 
7) Memberi Reward bagi guru yang dapat mengerjakan tugas dengan benar

c. Observasi dan Evaluasi

Dalam pelaksanaan pemberian reward yang dibawakan oleh peneliti untuk pertama kali pada siklus I ini terlihat pencapaian sebesar $74 \%$ dari seluruh aspek yang diobservasi dan dilakukan penilaian. Artinya masih membutuhkan pengulangan pada siklus berikutnya karena memang belum begitu memuaskan. Adapun hasil observasi penelitian terhadap aktivitas peneliti yang pada saat itu memberikan pengarahan akan uraikan pada tabel 1 berikut.

Tabel 1. Aspek Pemberian Penghargaan Oleh Fasilitator Pada Siklus I

\begin{tabular}{|c|c|c|c|c|c|c|c|c|}
\hline No & Penilaian & SB & B & SD & KB & TB & JML & $\%$ \\
\hline 1. & $\begin{array}{l}\text { Memusatkan perhatian kepada guru agar mengikuti } \\
\text { arahan yang diberikan oleh fasilitator }\end{array}$ & & $\mathbf{v}$ & & & & 4 & \\
\hline 2. & $\begin{array}{l}\text { Menjelaskan materi pelajaran dengan kalimat yang } \\
\text { memberikan motivasi }\end{array}$ & & & & $\mathrm{v}$ & & 2 & \\
\hline 3. & $\begin{array}{l}\text { Memuji dan menyanjung di depan guru yang lain jika } \\
\text { menjawab benar }\end{array}$ & & & & $\mathrm{v}$ & & 2 & \\
\hline 4. & $\begin{array}{l}\text { Memberikan tugas dengan suasana santai seperti } \\
\text { membuat rencana pelaksanaan pembelajaran dengan } \\
\text { beberapa model pembelajaran }\end{array}$ & & & $\mathrm{v}$ & & & 3 & \\
\hline 5. & Membahas tugas yang telah dikerjakan guru & & $\mathrm{v}$ & & & & 4 & $57 \%$ \\
\hline 6. & Membebaskan guru dari sebagian kewajiban & & & $\mathrm{v}$ & & & 3 & \\
\hline 7. & $\begin{array}{l}\text { Memberi Reward bagi guru yang dapat mengerjakan } \\
\text { tugas dengan benar }\end{array}$ & & & & $\mathrm{v}$ & & 2 & \\
\hline & $\begin{array}{l}\text { JUMLAH } \\
\text { KATEGORI }\end{array}$ & & 8 & 6 & $\begin{array}{c}6 \\
\text { 3aik }\end{array}$ & & 20 & \\
\hline
\end{tabular}

Sumber: Data Hasil Observasi, 2019

Keterangan:

$\begin{array}{lll}\text { SB } & \text { : Sangat baik } & =5 \\ \text { B } & \text { : Baik } & =4 \\ \text { CB } & \text { : Cuup baik } & =3 \\ \text { KB } & \text { : Kurang baik } & =2 \\ \text { TB } & \text { : Tidak Baik } & =1\end{array}$

Dari tabel di atas dapat diterangkan sebagai berikut:

1. Pada aspek Memusatkan perhatian kepada guru didapatkan skor dengan kategori baik

2. Pada aspek Menjelaskan materi pelajaran dengan kalimat yang memberikan motivasi didapatkan skor dengan kategori kurang baik

3. Pada aspek Memuji dan menyanjung didepan guru yang lain jika menjawab benar didapatkan skor dengan kategori kurang baik
4. Pada aspek Memberikan tugas dengan suasana santai didapatkan skor dengan kategori cukup baik

5. Pada aspek Membahas tugas yang telah dikerjakan guru didapatkan skor dengan kategori baik

6. Pada aspek Membebaskan guru dari sebagian kewajiban didapatkan skor dengan kategori cukup baik

7. Pada aspek Memberi Reward bagi guru yang dapat mengerjakan tugas dengan benar didapatkan skor dengan kategori kurang baik

\section{d. Refleksi}

Berdasarkan hasil observasi selama berlangsungnya kegiatan dan hasil evaluasi pada akhir pertemuan siklus dilakukan refleksi. Hasil refleksi ini dijadikan acuan untuk merencanakan penyempurnaan dan perbaikan 
siklus berikutnya. Semua tahap kegiatan tersebut mulai dari tahap perencanaan, pelaksanaan maupun observasi dan evaluasi dilakukan secara berulang-ulang melalui siklus-siklus sampai ada peningkatan sesuai yang diharapkan yaitu mencapai angka katagori'baik" dengan persentase 57\%, berarti belum memenuhi target yang ditetapkan, maka perlu bimbingan pada siklus II Peneliti mengadakan observasi terhadap Kepuasan kerja yang hasilnya sebagai berikut :

Tabel 2. Data Hasil Observasi Kepuasan kerja guru Siklus I

\begin{tabular}{clc}
\hline No & \multicolumn{1}{c}{ Kepuasan } & Persentase \\
\hline 1. & Pekerjaan & $40 \%$ \\
2. & Gaji & $60 \%$ \\
3. & Kesempatan Promosi & $53 \%$ \\
4. & Pengawasan & $40 \%$ \\
5. & Rekan Kerja & $73 \%$ \\
& & $\mathbf{5 3 \%}$ \\
\hline
\end{tabular}

Sumber: Data Olahan Penelitian, 2019

Berdasarkan hasil penelitian pada siklus I tersebut diketahui bahwa Kepuasan kerja guru berada pada kategori cukup baik dengan persentase $53 \%$. Keadaan ini menunjukkan bahwa pelaksanaan pembelajaran yang dilakukan oleh peneliti pada siklus I belum berhasil karena keberhasilan baru mencapai $53 \%$. Oleh sebab itu perlu dilakukan penelitian lanjut yakni siklus II.

\section{Siklus II}

\section{a. Perencanaan}

Pada siklus II, kegiatan yang dilaksanakan adalah mendiskusikan hambatanhambatan yang dialami dalam menyusun skenario pembelajaran dan pelaksanaan pembelajaran pada siklus I Adapun secara rinci uraian kegiatannya sebagai berikut :

Dalam tahap perencanaan atau persiapan tindakan ini, langkah-langkah yang dilakukan adalah sebagai berikut:

1. Menyusun tujuan operasional

2. Membuat lembar kerja dan menyusun lembar kerja guru untuk mengetahui kemampuan guru dalam membuat perangkat pembelajaran

3. Menyiapkan format pengamatan proses pembelajaran yang terdiri dari situasi kegiatan belajar mengajar, keaktifan guru dalam pembelajaran.
4. Menyusun lembar observasi untuk mengukur kedisiplinan

\section{b. Tindakan}

1) Memusatkan perhatian kepada guru agar mengikuti arahan yang diberikan oleh fasilitator

2) Menjelaskan materi pelajaran dengan kalimat yang memberikan motivasi

3) Memuji dan menyanjung di depan guru yang lain jika menjawab benar

4) Memberikan tugas dengan suasana santai seperti membuat rencana pelaksanaan pembelajaran dengan beberapa model pembelajaran

5) Membahas tugas yang telah dikerjakan guru

6) Membebaskan guru dari sebagian kewajiban

7) Memberi Reward bagi guru yang dapat mengerjakan tugas dengan benar

\section{c. Observasi}

Dalam pelaksanaan pemberian reward juga dilakukan pada siklus II, hal ini dilakukan untuk memperbaiki hasil pada siklus I ini terlihat pencapaian sebesar $91 \%$ dari seluruh aspek yang diobservasi dan dilakukan penilaian. Hasil pada siklus II terlihat bahwa pemberian reward pada guru telah optimal. Adapun hasil observasi penelitian terhadap 
aktivitas peneliti yang pada saat itu

tabel 3 berikut.

memberikan pengarahan akan uraikan pada

Tabel 3. Aspek Pemberian Reward Oleh Fasilitator Pada Siklus II

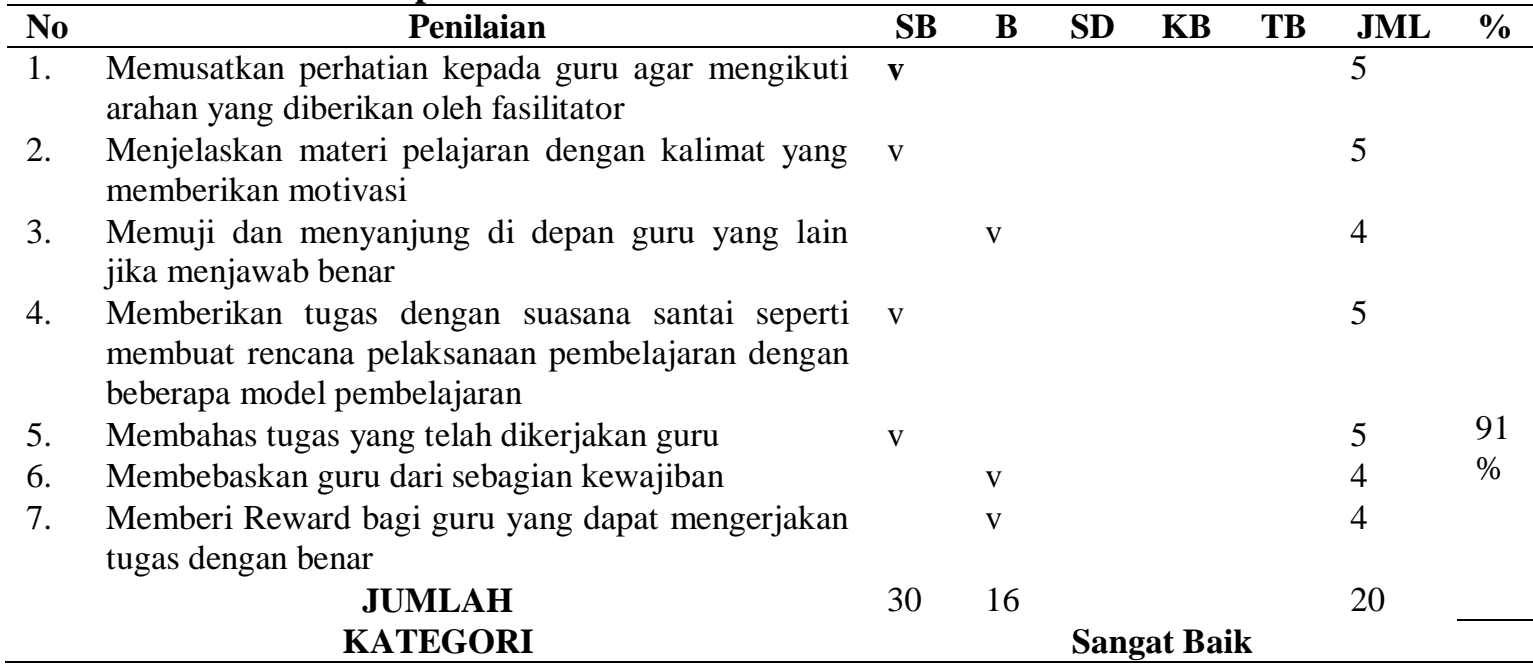

Sumber: Data Hasil Observasi, 2019

Berdasarkan data di atas dapat dijelaskan sebagai berikut:

1. Pada aspek Memusatkan perhatian kepada guru didapatkan skor dengan kategori sangat baik

2. Pada aspek Menjelaskan materi pelajaran dengan kalimat yang memberikan motivasi didapatkan skor dengan kategori sangat baik

3. Pada aspek Memuji dan menyanjung didepan guru yang lain jika menjawab benar didapatkan skor dengan kategori baik

4. Pada aspek Memberikan tugas dengan suasana santai didapatkan skor dengan kategori sangat baik
5. Pada aspek Membahas tugas yang telah dikerjakan guru didapatkan skor dengan sangat baik

6. Pada aspek Membebaskan guru dari sebagian kewajiban didapatkan skor dengan kategori baik

7. Pada aspek Memberi Reward bagi guru yang dapat mengerjakan tugas dengan benar didapatkan skor dengan kategori baik

Kemudian untuk mengetahui aspek kedisiplinan guru dapat diperhatikan hasil penilaian berikut ini.

Tabel 4. Aspek Kepuasan kerja guru Siklus II

\begin{tabular}{clc}
\hline No & \multicolumn{1}{c}{ Kepuasan } & Persentase \\
\hline 1. & Pekerjaan & $67 \%$ \\
2. & Gaji & $80 \%$ \\
3. & Kesempatan Promosi & $73 \%$ \\
4. & Pengawasan & $80 \%$ \\
5. & Rekan Kerja & $100 \%$ \\
& & $\mathbf{8 0 \%}$ \\
\hline
\end{tabular}

Sumber : Data hasil Observasi, 2019 
Berdasarkan hasil penelitian pada siklus I tersebut diketahui bahwa Kepuasan kerja guru berada pada kategori sangat baik dengan persentase $80 \%$. Bila dibandingkan kedisiplinan guru antara siklus I dan Siklus II terjadi peningkatan yang mencolok. Untuk lebih jelasnya dapat dilihat pada tabel berikut ini.

Tabel 5. Perbandingan Kepuasan kerja Antara Siklus I Dan Siklus II

\begin{tabular}{ccc}
\hline KET & PERSENTASE KEPUASAN KERJA & KATEGORI \\
\hline SIKLUS I & $53 \%$ & Cukup Baik \\
SIKLUS II & $80 \%$ & Sangat baik \\
\hline
\end{tabular}

Sumber: Data Olahan Penelitian, 2019

Berdasarkan data pada tabel 5 diketahui bahwa secara umum terlihat peningkatan Kepuasan kerja guru.
Perbandingan kepuasan kerja guru antara siklus I dan Siklus II juga ditampilkan dalam bentuk diagram batang berikut ini.

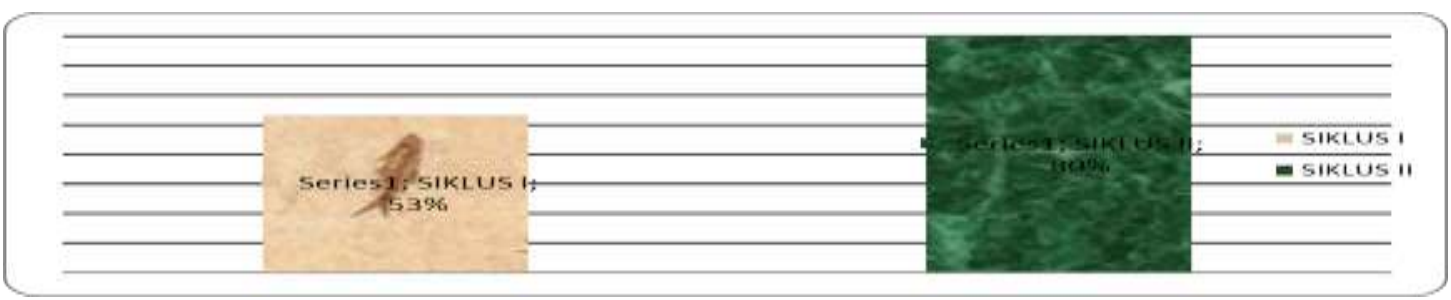

Gambar 2. Perbandingan Kepuasan kerja Antara Siklus I Dan Siklus II

\section{Pembahasan}

Berdasarkan data tersebut di atas dapat diketahui, bahwa pada pengamatan awal di SLB Negeri Duri, Kepuasan kerja guru pada siklus I tergolong cukup baik, hal ini disebabkan oleh kurangnya kesadaran guru tentang pentingnya Kepuasan kerja guru. Setelah diberikan tindakan melalui siklus I, ada peningkatan Kepuasan kerja guru di SLB Negeri Duri meningkat.

Jika diperhatikan Kepuasan kerja guru pada siklus II meningkat dibandingkan dengan siklus I. artinya bahwa tindakan yang dilakukan pada siklus II berdampak terhadap Kepuasan kerja guru dalam menjalankan tugas. Refleksi pada siklus pertama diperoleh berdasarkan hasil analisis data untuk tiap-tiap langkah pelaksanaan tindakan yang telah dideskripsikan peneliti pada tahap ini, dan telah didiskusikan dengan observer, maka diketahui kelemahan-kelemahan pembelajaran siklus pertama sebagai berikut:

1) Beberapa aspek aktivitas yang dilalkukan peneliti masih kurang sempurna, yaitu dalam mengawasi dan memberikan bimbingan, dorongan atau bantuan pada guru agar pembelajaran berjalan lancar, dan guru memberikan penilaian terhadap kinerja guru.

2) Dalam proses pembelajaran masih banyak yang kurang keseriusannya, sehingga banyak yang tidak memperhatikan dalam proses pembelajaran.

3) Kemampuan guru secara keseluruhan masih belum mencapai indicator keberhasilan yang telah ditetapkan dalam penelitian ini yaitu mencapai angka $70 \%$ yang berkriteria baik, oleh sebab itu pada siklus kedua peneliti akan berusaha untuk menaikkan Kepuasan kerja guru. 
Berdasarkan kelemahan-kelemahan yang telah dilakukan oleh guru tersebut, maka guru sekaligus merangkap sebagai peneliti merencakan untuk memperbaiki kelemahan tersebut pada siklus II, adapun upaya yang akan dilakukan adalah sebagai berikut:

1) Peneliti lebih memaksimalkan untuk melaksanakan langkah-langkah pembelajaran, agar proses pembelajaran dapat berjalan lancar.

2) Menjelaskan materi pelajaran dengan kalimat yang memberikan motivasi.

3) Peneliti Memuji dan menyanjung didepan guru yang lain jika menjawab benar.

Jika diperhatikan hasil siklus kedua, Kepuasan kerja lebih tinggi dibanding dengan siklus pertama. Artinya tindakan yang diberikan pada siklus kedua berdampak lebih baik dari tindakan pada siklus pertama. Hal ini memberikan gambaran bahwa untuk bisa membantu guru melatih menemukan sendiri isi dari sebuah materi, guru membutuhkan waktu untuk memahami materi tersebut. Pada awalnya guru perlu dibimbing secara intensif, namun secara berangsur-angsur siswa diberi kesempatan untuk bisa menemukannya tanpa bantuan guru.

Pembatasan waktu yang diberikan untuk mengerjakan tugas yang diajukan peneliti kepada guru berdampak pula kepada hasil yang baik. Guru tidak membuang-buang waktu hingga dua kali pertemuan untuk menyelesaikan satu permasalahan. Bimbingan khusus yang ditujukan kepada sebagian kecil guru juga menunjukkan hasil yang baik. Ini terlihat dari kemampuan guru pada siklus kedua mencapai indicator yang telah ditetapkan, yaitu kemampuan guru yang berkategori baik yang dicapai adalah sebesar $80 \%$ dan pada siklus II berada pada kriteria sangat baik, artinya angka ini telah melebihi angka keberhasilan yang telah ditetapkan.

\section{KESIMPULAN}

'Dari uraian pengolahan data dan pembahasan didapatkan kesimpulan sebagai berikut:
1) Aspek pemberian reward yang dibawakan oleh tutor diketahui bahwa dari siklus I meningkat pada siklus II. Jika pada siklus I mendapatkan skor sebesar 20 maka pada siklus II sudah lebih baik dengan mendapatkan perolehan skor sebesar 32 .

2) Pada aspek Kepuasan kerja guru didapatkan pada siklus I sebesar 53\% dengan kategori dukup baik dan pada siklus II meningkat menjadi $80 \%$ dengan kategori sangat baik.

Dari simpulan tersebut di atas, disarankan :

1. Kepada guru-guru khususnya guru di SLB Negeri Duri, dapat meningkatkan kinerjanya melalui kepuasan kerja, agar tujuan pembelajaran bagi peserta didik dapat tercapai.

2. Kepada instansi terkait, agar lebih memperhatikan pihak sekolah guna terwujudnya sekolah yang berkualitas dengan memiliki guru yang memiliki Kepuasan kerja yang tinggi yang mendukung kinerja yang maksimal pula.

\section{DAFTAR PUSTAKA}

Arikunto, S., Suhardjono, S., \& Supardi. (2012). Penelitian Tindakan Kelas. Jakarta: Bumi Aksara.

Basri, M. (2019). Meningkatkan Profesionalisme Guru Membuat Rencana Pelaksanaan Pembelajaran (RPP) Melalui Supervisi Bimbingan Pribadi Di SDN 91/IX Rengas Bandung. Jurnal PAJAR (Pendidikan dan Pengajaran), 3 (5), 1003-1014.

Bastian, B. (2019). Analisis Keterampilan Dasar Mengajar Guru dalam Melaksanakan Pembelajaran di Sekolah Dasar. Jurnal PAJAR (Pendidikan dan Pengajaran), 3(6), 1357-1365. DOI : http://dx.doi.org/10.33578/pjr.v3i6.789.

Candra, O \& Yanto, D.T.P. (2020). The Active Learning Strategy "Everyone Is A Teacher Here" To Improve Student Learning Outcomes. Jurnal PAJAR (Pendidikan dan Pengajaran), 4(3), 
616-623.

DOI

http://dx.doi.org/10.33578/pjr.v4i2.799.

Dewi, Y.E., \& Kurniaman, O. (2019). Analisis Keterampilan Dasar Menjelaskan oleh Guru Dalam Mengajarkan Membaca Permulaan Siswa Tunagrahita di SDLB Kasih Ibu Pekanbaru. Primary: Jurnal Pendidikan Guru Sekolah Dasar, 8 (1), 37-46.

DOI: http://dx.doi.org/10.33578/jpfkip.v8i1.6 361.

Kurniaman, O., Fauziah, E., \& Noviana, E. (2021). How To Teach Deaf Students In Elementary Schools?. JP2SD (Jurnal Pemikiran Dan Pengembangan Sekolah Dasar), 9(1), 48-58.

Kemmis \& Mc. Taggart. (2010). The Action Research Planner. Geelong: Deaken Univercity Press

Kurniaman, O., \& Sismulyasih, N. S. (2019). The Influence of The Big Book Media Has The Character of Conservation in Early Reading. ELS Journal on Interdisciplinary Studies in Humanities, 2(1), 141-147.

Kurniaman, O., Oktari, C., \& Pahrurazi, P. (2019). The Implementation of Teaching Materials Reading Graphic Organizers in Elementary Schools. Lensa: Kajian
Kebahasaan, Kesusastraan, dan Budaya, 9(2), 105-119.

Katrin, S. (2019). Pengaruh Pola Kepemimpinan Kepala Sekolah terhadap Kinerja Guru Di SD Negeri 6 Mandau. Jurnal PAJAR (Pendidikan dan Pengajaran), 3(5), 1102-1112.

Mangkunegara A., A. (2001). Manajemen Sumber Daya Manusia Perusahaan, Bandung: PT. Remaja Rosda Karya.

Novianti, R., Puspitasari, E., \& Maria, I. (2021). Parents' Involvement in Children's Learning Activities during the Covid-19 Pandemic. Jurnal PAJAR (Pendidikan dan Pengajaran), 5(2), 384-390. DOI http://dx.doi.org/10.33578/pjr.v5i2.822.

Schmidt, M., and Brown, I. (2015). Education of Children with Intellectual Disabilities in Slovenia. Journal of Policy and Practice in Intellectual Disabilities, 2(4), 1-10.

Tarmansyah. (2009). Pelaksanaan Pendidikan Inklusif SD Negeri 03 Alai Padang Utara Kota Padang (Studi Pelaksanaan Pendidikan di Sekolah Ujicoba Sistem Pendidikan Inkusif). Pedagogi, Jurnal Ilmiah Ilmu Pendidikan, 9(1), 12-20. 